\title{
Spontaneous aneurysmal subarachnoid haemorrhage in a child with multiply recurrent posterior fossa juvenile pilocytic astrocytoma
}

\author{
Dillon Y Chen, ${ }^{1}$ Michael L Levy, ${ }^{2}$ John Ross Crawford ${ }^{1}$
}

'Department of Neurosciences and Pediatrics, University of California San Diego, San Diego, California, USA ${ }^{2}$ Department of Neurosurgery, University of California San Diego, San Diego, California, USA

Correspondence to Dr John Ross Crawford, jrcrawford@ucsd.edu

Accepted 23 November 2016

\section{DESCRIPTION}

A 9-year-old boy with a history of posterior fossa juvenile pilocytic astrocytoma presented to the emergency room for lethargy and worsening headache. Three years earlier, he underwent near total resection of the tumour. Owing to the progressive disease, he had a second resection and underwent conformal radiation therapy, totalling $5040 \mathrm{cGy}$. In the following 2 years, he reported of severe headaches. Multiple brain MRIs with and without contrast and head CTs without contrast did not reveal disease recurrence or significant abnormality. On the day of presentation, the child again reported of a severe headache and was brought to the emergency department (ED). In the $\mathrm{ED}$, he rapidly decompensated. Neurological examination showed a large and non-reactive right pupil. CT of the head revealed a spontaneous fresh haemorrhage in the right cerebellum. CT angiography showed an abnormal tangle of vessels off the right posterior-inferior cerebellar artery (figure 1A-C). Neurosurgical intervention confirmed the presence of an aneurysm. The child died 13 days after the presentation.

Radiotherapy is a part of the standard treatment for many paediatric brain tumours. It is, however, not without risk. Cranial irradiation can cause a multitude of problems including stroke, neuroendocrine abnormality, cognitive deficit and vascular malformations. ${ }^{1}$ Children who report of severe headaches postcranial radiation have a greater risk of neurovascular events. ${ }^{2}$ While vascular complications after cranial radiotherapy are well documented, aneurysm is rare. A retrospective chart review study published in 2006 showed that $3 \%$ of the 224 paediatric patients who received cranial radiotherapy developed aneurysm and one developed a rupture aneurysm. ${ }^{3}$ However, although rare, recurrent headaches in a patient with prior radiation therapy should raise suspicion of aneurysm even in the presence of normal MRI. Therefore, CT or conventional angiography may be considered.

\section{Learning points}

- Cranial irradiation, while it can be a part of standard therapy for paediatric brain tumour, is not without its risk, and has been shown to cause a number of problems, including vascular malformations.

- Consider CT or conventional angiography to rule out aneurysm for patients with headache with history of cranial irradiation.

Contributors JRC and MLL were involved in diagnosis and treatment of the patient. DYC and JRC did the literature search and wrote the manuscript. JRC is responsible for the overall content as the guarantor.

Competing interests None declared.

Patient consent Obtained.

Provenance and peer review Not commissioned; externally pee reviewed.

\section{REFERENCES}

1 Campen CJ, Kranick SM, Kasner SE, et al. Cranial irradiation increases risk of stroke in pediatric brain tumor survivors. Stroke 2012;43:3035-40.

2 Kranick SM, Campen CJ, Kasner SE, et al. Headache as a risk factor neurovascular events in pediatric brain tumor patients. Neurology 2013;80:1452-6.

3 Keene DL, Johnston DL, Grimard L, et al. Vascular complications of cranial radiation. Childs Nerv Syst 2006;22:547-55.
To cite: Chen DY, Levy ML, Crawford JR. BMJ Case Rep Published online: [please include Day Month Year] doi:10.1136/bcr-2016217583

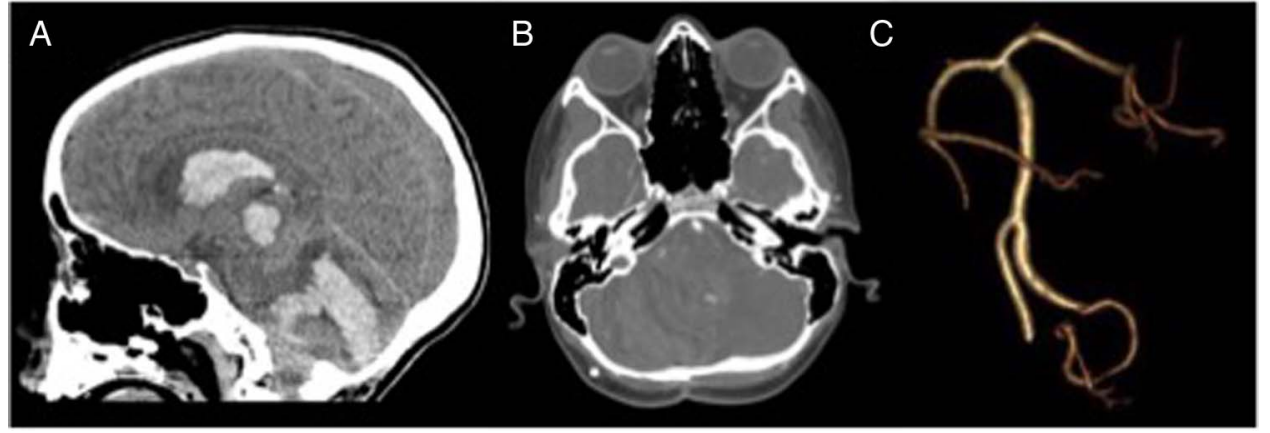

Figure 1 CT head angiography. (A) Large posterior fossa haemorrhage with extension into the ventricular system. (B) Demonstration and (C) three-dimensional reconstruction of prominent tonsillar branch arising from the PICA with a small abnormal irregular vessel, likely a small aneurysm. 
Copyright 2016 BMJ Publishing Group. All rights reserved. For permission to reuse any of this content visit http://group.bmj.com/group/rights-licensing/permissions.

BMJ Case Report Fellows may re-use this article for personal use and teaching without any further permission.

Become a Fellow of BMJ Case Reports today and you can:

- Submit as many cases as you like

- Enjoy fast sympathetic peer review and rapid publication of accepted articles

- Access all the published articles

- Re-use any of the published material for personal use and teaching without further permission

For information on Institutional Fellowships contact consortiasales@bmjgroup.com

Visit casereports.bmj.com for more articles like this and to become a Fellow 